\title{
Genetic Response of Sugarcane (Saccharum officinarum L.) Genotypes to Varying Concentrations of Cytokinins for in vitro Shoot Multiplication
}

\author{
Suresh Yadav ${ }^{1}$, T.E. Nagaraja ${ }^{2}$, H.C. Lohithaswa ${ }^{2}$, K.V. Shivakumar ${ }^{2}$, \\ Poonam Kumari Yadav ${ }^{3}$, Poonam Yadav ${ }^{4}$, Ganpat Louhar ${ }^{5}$ and Jagdish Yadav \\ ${ }^{1}$ Division of Genetics, IARI, New Delhi, India \\ ${ }^{2}$ Department of Genetics and Plant Breeding, V.C. Farm, Mandya, University of Agricultural \\ Sciences, Bangalore, India \\ ${ }^{3}$ Department of soil science and agricultural chemistry, SKN College of Agriculture (SKNAU), \\ Jobner, 303329 Jaipur, India \\ ${ }^{4}$ Department of Livestock Production and Management, SKN College of Agriculture \\ (SKNAU), Jobner, 303329 Jaipur, India \\ ${ }^{5}$ Division of soil science and agricultural chemistry, IARI, New Delhi, India \\ ${ }^{6}$ Division of Plant Pathology, Indian Agricultural Research Institue, New Delhi, 110012, India
}

*Corresponding author

\begin{tabular}{|c|c|}
\hline $\begin{array}{l}\text { K e y w o r d s } \\
\text { In vitro Shoot } \\
\text { multiplication, } \\
\text { Sugarcane, 6- } \\
\text { Benzylamminopuri } \\
\text { ne (6-BAP), Kinetin }\end{array}$ & $\begin{array}{l}\text { Skoog, 1962) medium containing } 1.0 \mathrm{mg} / \mathrm{l} \text { kinetin. The multiplication response of two } \\
\text { sugarcane genotypes was studied under five levels of } 6 \text {-Benzylaminopurine }(0,0.5,1,1.5 \text { and } 2 \\
\text { mg/l) and five levels of kinetin }(0,0.25,0.5,1.0 \text { and } 1.5 \mathrm{mg} / \mathrm{l}) \text { in completely randomized design } \\
\text { with } 5 \times 5 \times 2 \text { factorial treatment combinations. Analysis of variance (ANOVA) showed that the } \\
\text { interaction effects of } 6 \text {-benzlyaminopurine (6-BAP), kinetin and the sugarcane genotypes on } \\
\text { number of shoots per explant, shoot length, and chlorophyll content was highly significant ( } \mathrm{p}< \\
0.001) \text {, except for number of leaves. Multiplication of the cultures was obtained by using }\end{array}$ \\
\hline Article Info & genotype Co 86032 was obtained when MS media supplemented with $1.0 \mathrm{mg} / \mathrm{l} 6-\mathrm{BAP}$ and 0.5 \\
\hline $\begin{array}{l}\text { Accepted: } \\
\text { 10 January } 2019 \\
\text { Available Online: } \\
10 \text { February } 2019\end{array}$ & $\begin{array}{l}\mathrm{mg} / \mathrm{l} \text { kinetin as this genotype produce } 32.5 \text { shoots per explant with } 0.32 \mathrm{~cm} \text { shoot length, } 2.83 \\
\text { eaves and chlorophyll content of } 20.78 \mathrm{mg} / \mathrm{g} \text {. best performance of CoVC- } 18061 \text { with respect to } \\
\text { chlorophyll content }(22.83 \mathrm{mg} / \mathrm{g}) \text { was obtained on MS medium fortified with combination of } \\
1.5 \mathrm{mg} / \mathrm{l} \text { BAP and } 0.5 \mathrm{mg} / \mathrm{l} \text { kinetin after } 30 \text { days of culture transferred to multiplication media. }\end{array}$ \\
\hline & $\begin{array}{l}\text { The performance of genotype for all characters was very poor in MS medium amended with } \\
\text { other combinations. Thus, the optimized protocol is useful for rejuvenation, rapid in vitro } \\
\text { propagation and production of large quantity of quality plants. }\end{array}$ \\
\hline
\end{tabular}




\section{Introduction}

Sugarcane (Saccharum officinarum L.) is a monocotyledonous crop that belongs to the family of grasses, Poaceae. It is an octoploid crop with chromosome number of $2 \mathrm{n}=80$ (Baksha et al., 2002). It is a tall perennial tropical grass that tillers at the base, grows 34 meters tall and about $5 \mathrm{~cm}$ in diameter. Sugarcane is one of the most efficient convertors of solar energy into sugar and other renewable forms of energy and hence produced primarily for its ability to store high concentrations of sucrose, or sugar, in the internodes of the stem. Varieties of sugarcane are highly heterogeneous and generally multiplied by stem cuttings with each cutting or sett having two or three buds and the rate of propagation is very slow, usually 1:10 in a year (Khan et al., 2008). Lack of rapid multiplication procedures and continuous contamination by systemic disease is the serious economic problem to multiply an elite genotype of sugarcane in the open field (Lal et al., 2001). In addition, the conventional propagation method requires large quantity of seed, land and cutting implements used for seed cane preparation play a significant role in facilitating cross contamination during seed cane preparation (Mamum et al., 2004). Besides the costly transport of the bulky cane cuttings, harbour many pests and diseases with accumulation of disease over vegetative cycles leading to further yield and quality decline over the years. Micropropagation is a technique through which genetically identical plants of selected genotype multiplied vegetativelly and rapidly by aseptic in vitro culture of meristematic regions under controlled nutritional and environmental conditions. Unlike the conventional propagation method, it is the only realistic means of achieving rapid and large scale production of disease free, quality planting materials in sugarcane and an alternative approach for fast multiplication of a variety in its original form. It is very effective in producing disease free, rejuvenation and subsequent mass propagation of well adapted and promising varieties facing gradual deterioration in yield, quality and vigour due to accumulation of pathogens during prolonged vegetative cultivation and hence sustains the productive potential of sugarcane crops for a longer period. Furthermore, micropropagated sugarcane plants were reported to produce high cane and sugar yield as compared to their donors under similar agronomic management practices.

Considering the diverse limitations of conventional method and potential of tissue culture techniques, researchers have developed protocols for sugarcane in vitro propagation using shoot tip explants. Every new variety or clone needs an efficient protocol to get rapid in vitro propagation (Geetha and Padmanaban, 2004). Rapid clonal propagation of sugarcane planting materials depends on the genotype and the combination of plant growth regulators used. The nutritional requirement for in vitro propagation of sugarcane should be according to genotype and explant used. Therefore, combinations of plant growth regulators required for in vitro propagation responses vary from genotype to genotype (Pathak et al., 2009). The nutritional requirement for every sugarcane variety is specific. Therefore, this study was carried out with the objective to optimize protocol for in vitro shoot multiplication of two genotypes viz., Co 86032 and CoVC-18061.

\section{Materials and Methods}

\section{Treatments}

The study was conducted at Zonal Agricultural Research Station, V.C. Farm, Mandya (University of Agricultural Sciences, Bengaluru). The experiment consisted of two 
genotypes, Co 86032 and CoVC-18061 tested on six combinations of 6-BAP and kinetin (Table 1). The laboratory experiments were laid out in CRD with four replications at Sugarcane Tissue Culture Laboratory, Jaggery Park, V. C. Farm, Mandya.

\section{Shoot proliferation}

Micro shoots initiated from shoot tip explants having similar size were used for the experiment after maintaining the initiated cultures on plant growth regulator free medium to avoid the carry over effect of initiation medium. MS medium was used with different combinations of 6-BAP $(0,0.5,1.0$, 1.5 and $2.0 \mathrm{mg} / \mathrm{l})$ and kinetin $(0,0.25,0.5,1.0$ and $1.5 \mathrm{mg} / \mathrm{l})$ in factorial treatment combinations along with $30 \mathrm{~g} / \mathrm{l}$ sucrose as a carbon source. The $\mathrm{pH}$ of the medium was adjusted to 5.8 before autoclave at $121^{\circ} \mathrm{C}$ and 15 psi for 20 minutes. The experiment was carried out at a temperature of $24^{\circ} \mathrm{C} \pm 2{ }^{\circ} \mathrm{C}$ with 16hrs light and 8hrs dark photoperiod regimes maintained under fluorescent light having 2500-3000 lux light intensity with $65 \%$ to $70 \%$ relative humidity of the growth chamber. The experiment was laid out in completely randomized design with the three factor factorial treatment combinations arrangements. Data on number of shoots per culture, shoot length, number of leaves and average chlorophyll content was collected after 30 days of culture. The collected data were subjected to analysis of variance (ANOVA).

\section{Results and Discussion}

\section{In vitro shoot multiplication}

Analysis of variance (ANOVA) revealed that the interaction effects of genotype, 6-BAP and kinetin was highly significant on the number of shoots per explant, shoot length (cm) and chlorophyll content except for number of leaves per shoot. Formation of multiple shoots occurs at very low rate within 30 days when explants were cultured on MS medium without plant growth regulators (Table 2). Among the different combinations of 6-BAP and kinetin used, Co 86032 produced highest number of shoots per explant (32.5) with $6.32 \mathrm{~cm}$ shoot length, 2.83 leaves per shoot and chlorophyll content of $20.78 \mathrm{mg} / \mathrm{g}$ on MS medium fortified with 1.0 $\mathrm{mg} / \mathrm{l} 6-\mathrm{BAP}$ and $0.5 \mathrm{mg} / \mathrm{l}$ kinetin (Table 2). Optimum shoot multiplication for CoVC18061 obtained in MS medium containing 1.5 $\mathrm{mg} / \mathrm{l}$ 6-BAP and $0.5 \mathrm{mg} / \mathrm{l}$ kinetin as this genotype produced maximum shoots per explant (27.75), with $7.03 \mathrm{~cm}$ shoot length, 2.81 leaves per shoot and $22.83 \mathrm{mg} / \mathrm{g}$ chlorophyll content (Table 2). Increase in kinetin content from 0.25 to $0.5 \mathrm{mg} / \mathrm{l}$ with the $1.0 \mathrm{mg} / \mathrm{l}$ 6-BAP for genotype Co 86032 showed a significant increase in the number of shoots per explant (from 19.75 to 32.75), number of leaves (from 2.42 to 2.83 ), shoot length (from 4.34 to 6.32) and chlorophyll content (from 12.73 to 20.78) (Table 2) and for genotype CoVC-18061 increase in concentration of 6-BAP from 0.25 to $1.5 \mathrm{mg} / \mathrm{l}$ with the $0.5 \mathrm{mg} / \mathrm{l}$ kinetin showed a significant increase in the number of shoots per explant (from 17.10 to 27.75), number of leaves (from 2.41 to 2.81), average shoot length (from 5.15 to 7.03) and chlorophyll content (from 13.35 to 22.83) (Table 2). however, further increase in $6-\mathrm{BAP}$ to $1.5 \mathrm{mg} / \mathrm{l}$ with increase in kinetin to $1 \mathrm{mg} / \mathrm{l}$ significantly reduced the number of shoots per explant, number of leaves per shoot, shoot length and chlorophyll content in both the genotypes (Table 2). This indicates that higher concentrations of cytokinins inhibit cell division, shoot multiplication and elongation in sugarcane genotypes.

The influence of both the varieties on number of shoots per culture, shoot length, number of leaves and chlorophyll content were nonsignificant $(\mathrm{p}<0.01)$. 
Table.1 Media with six different combination of 6 benzylamminopurine (6-BAP) and kinetin for shoot multiplication

\begin{tabular}{|c|c|}
\hline Media code & Cytokinins combinations \\
\hline T1 & $0.0 \mathrm{mg} / \mathrm{l}$ 6-BAP $+0.0 \mathrm{mg} / \mathrm{l} \mathrm{Kinetin}$ \\
\hline $\mathbf{T 2}$ & $\begin{array}{l}1.0 \mathrm{mg} / \mathrm{l} 6-\mathrm{BAP}+0.25 \mathrm{mg} / \mathrm{l} \\
\text { Kinetin }\end{array}$ \\
\hline T3 & $1.0 \mathrm{mg} / \mathrm{l}$ 6-BAP + $0.5 \mathrm{mg} / \mathrm{l} \mathrm{Kinetin}$ \\
\hline T4 & $2.0 \mathrm{mg} / \mathrm{l}$ 6-BAP + $1.0 \mathrm{mg} / \mathrm{l} \mathrm{Kinetin}$ \\
\hline T5 & $1.5 \mathrm{mg} / \mathrm{l} 6-\mathrm{BAP}+0.5 \mathrm{mg} / \mathrm{l} \mathrm{Kinetin}$ \\
\hline T6 & $0.5 \mathrm{mg} / \mathrm{l}$ 6-BAP + $1.5 \mathrm{mg} / \mathrm{l} \mathrm{Kinetin}$ \\
\hline
\end{tabular}

Table.2 Interaction effects of 6-benzylaminopurine, kinetin and genotypes on in vitro shoot multiplication after 30 days

\begin{tabular}{|c|c|c|c|c|c|c|c|c|}
\hline & \multicolumn{3}{|c|}{ Co-86032 } & \multicolumn{3}{c|}{ CoVC-18061 } \\
\hline TREATMENTS & $\begin{array}{l}\text { Number of } \\
\text { shoots per } \\
\text { explants }\end{array}$ & $\begin{array}{l}\text { Number of } \\
\text { leaves per } \\
\text { shoot }\end{array}$ & $\begin{array}{l}\text { Shoot } \\
\text { length } \\
(\mathrm{cm})\end{array}$ & $\begin{array}{l}\text { Chlorophyll } \\
\text { content } \\
(\mathrm{mg} / \mathrm{g})\end{array}$ & $\begin{array}{l}\text { Number of } \\
\text { shoots per } \\
\text { explants }\end{array}$ & $\begin{array}{l}\text { Number of } \\
\text { leaves per } \\
\text { shoot }\end{array}$ & $\begin{array}{l}\text { Shoot } \\
\text { length } \\
(\mathrm{cm})\end{array}$ & $\begin{array}{l}\text { Chlorophyll } \\
\text { content } \\
(\mathrm{mg} / \mathrm{g})\end{array}$ \\
\hline T1 & 9.51 & 2.25 & 3.21 & 11.85 & 6.25 & 2.38 & 3.20 & 11.33 \\
\hline T2 & 19.75 & 2.42 & 4.34 & 12.73 & 17.10 & 2.41 & 5.15 & 13.35 \\
\hline T3 & 32.75 & 2.83 & 6.32 & 20.78 & 22.45 & 2.66 & 5.80 & 13.75 \\
\hline T4 & 21.50 & 2.55 & 4.39 & 13.62 & 20.25 & 2.76 & 6.85 & 21.30 \\
\hline T5 & 26.75 & 2.60 & 5.10 & 16.55 & 27.75 & 2.81 & 7.03 & 22.83 \\
\hline T6 & 20.30 & 2.20 & 4.95 & 13.90 & 18.21 & 2.49 & 5.60 & 16.40 \\
\hline SEM & 3.4 & 0.2 & 1.8 & 2.3 & 3.4 & 0.2 & 1.8 & 2.3 \\
\hline CD@1\% & 13.1 & 0.8 & 3.2 & 9.0 & 13.1 & 0.8 & 3.2 & 9.0 \\
\hline CV & 32.89 & 15.75 & 36.51 & 29.21 & 32.89 & 15.75 & 36.51 & 29.21 \\
\hline RESULS & S & NS & S & S & S & NS & S \\
\hline
\end{tabular}


Table.3 Effects of genotypes on shoot multiplication

\begin{tabular}{|l|l|l|l|l|}
\hline Genotypic effect & Number of shoots & Shoot length & Number of leaves & Chlorophyll content \\
\hline Co 86032 & 17.37 & 3.47 & 2.19 & 15.40 \\
\hline CoVC-18061 & 14.49 & 3.13 & 2.01 & 13.57 \\
\hline
\end{tabular}

Table.4 Effect of different combinations of 6-benzylaminopurine and kinetin on in vitro shoot multiplication of two sugarcane genotypes

\begin{tabular}{|c|c|c|c|c|c|c|c|c|}
\hline \multirow{2}{*}{$\begin{array}{l}\text { Effect of } \\
\text { hormonal } \\
\text { combination }\end{array}$} & \multicolumn{4}{|c|}{ Co 86032} & \multicolumn{4}{|c|}{ CoVC-18061 } \\
\hline & $\begin{array}{l}\text { Number } \\
\text { of } \\
\text { shoots }\end{array}$ & $\begin{array}{l}\text { Shoot } \\
\text { length }\end{array}$ & $\begin{array}{l}\text { Number } \\
\text { of leaves }\end{array}$ & $\begin{array}{l}\text { Chlorophy } \\
\text { ll content }\end{array}$ & $\begin{array}{l}\text { Number } \\
\text { of shoots }\end{array}$ & $\begin{array}{l}\text { Shoot } \\
\text { length }\end{array}$ & $\begin{array}{l}\text { Number } \\
\text { of leaves }\end{array}$ & $\begin{array}{l}\text { Chlorophy } \\
\text { ll content }\end{array}$ \\
\hline T1 & 6.5 & 1.34 & 2.22 & 7.61 & 4.25 & 1.76 & 2.26 & 6.33 \\
\hline $\mathbf{T} 2$ & 12.75 & 1.85 & 2.25 & 10.54 & 9.25 & 3.01 & 2.38 & 8.13 \\
\hline T3 & 22.75 & 3.91 & 2.63 & 14.21 & 13.45 & 3.15 & 2.06 & 11.32 \\
\hline T4 & 16.14 & 3.53 & 2.55 & 12.16 & 12.13 & 3.23 & 2.73 & 10.75 \\
\hline T5 & 14.5 & 3.52 & 2.53 & 13.23 & 18.25 & 5.03 & 2.13 & 15.31 \\
\hline T6 & 12.16 & 3.65 & 2.55 & 11.61 & 12.1 & 4.85 & 1.80 & 13.85 \\
\hline
\end{tabular}


Fig.1 Effect of different combinations of cytokinins on shoot multiplication in genotype Co 86032 a. $0.0 \mathrm{mg} / \mathrm{l}$ 6-BAP + $0.0 \mathrm{mg} / \mathrm{l}$ kinetin, b. $1.0 \mathrm{mg} / \mathrm{l}$ 6-BAP + $0.25 \mathrm{mg} / \mathrm{l} \mathrm{kinetin,} \mathrm{c.} 1.0 \mathrm{mg} / \mathrm{l}$ 6-BAP + $0.5 \mathrm{mg} / \mathrm{l}$ kinetin, d. $2.0 \mathrm{mg} / \mathrm{l}$ 6-BAP + $1.0 \mathrm{mg} / \mathrm{l} \mathrm{kinetin,} \mathrm{e.} 1.5 \mathrm{mg} / \mathrm{l}$ 6-BAP + $0.5 \mathrm{mg} / \mathrm{l}$ kinetin and f. $0.5 \mathrm{mg} / \mathrm{l}$ 6-BAP $+1.5 \mathrm{mg} / \mathrm{l}$ kinetin
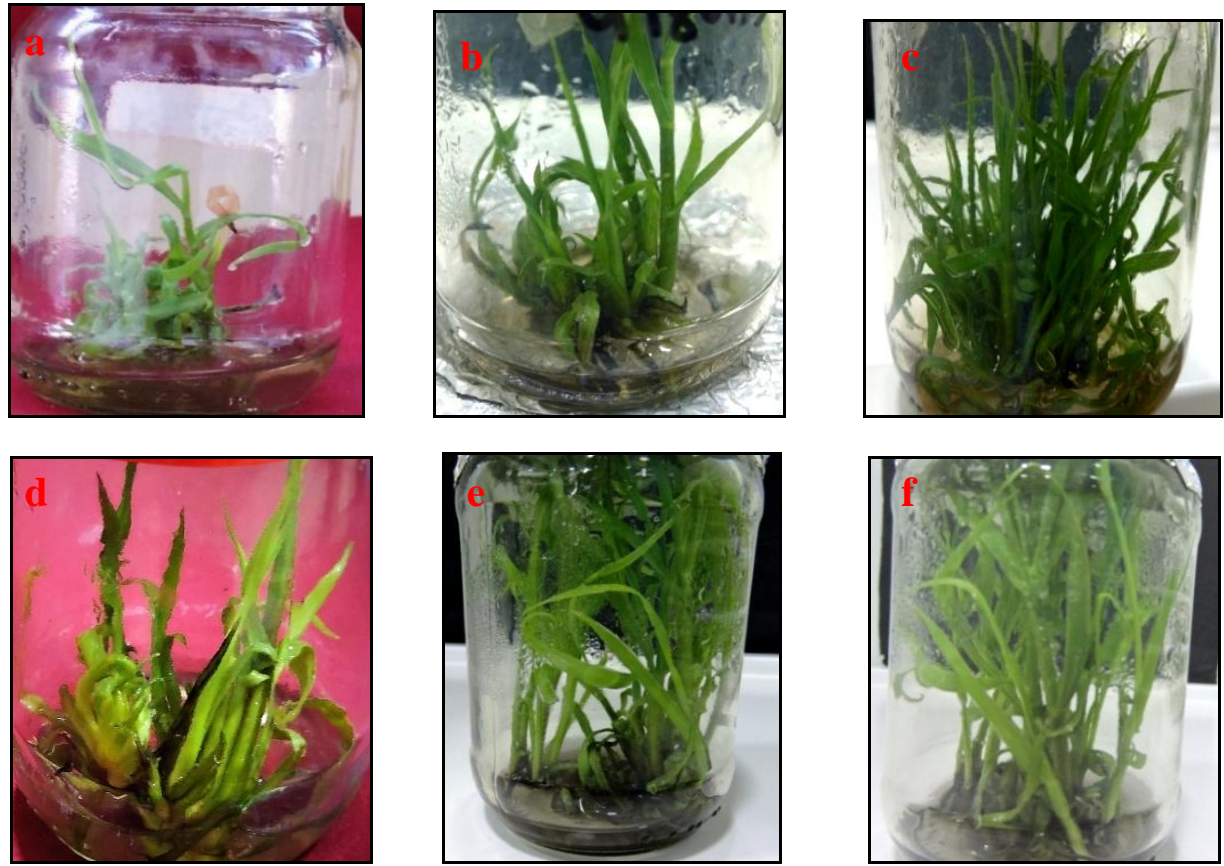

Fig.2 Effect of different levels of cytokinins on shoot multiplication in genotype CoVC-18061 a. $0.0 \mathrm{mg} / \mathrm{l}$ 6-BAP + $0.0 \mathrm{mg} / \mathrm{l}$ kinetin, b. $1.0 \mathrm{mg} / \mathrm{l} \mathrm{6-BAP}+0.25 \mathrm{mg} / \mathrm{l} \mathrm{kinetin,} \mathrm{c.} 1.0 \mathrm{mg} / \mathrm{l}$ 6-BAP + $0.5 \mathrm{mg} / \mathrm{l} \mathrm{kinetin,} \mathrm{d.} 2.0 \mathrm{mg} / \mathrm{l}$ 6-BAP $+1.0 \mathrm{mg} / \mathrm{l} \mathrm{kinetin,} \mathrm{e.} 1.5 \mathrm{mg} / \mathrm{l} 6-\mathrm{BAP}+0.5 \mathrm{mg} / \mathrm{l} \mathrm{kinetin}$ and f. $0.5 \mathrm{mg} / \mathrm{l} 6-\mathrm{BAP}+1.5 \mathrm{mg} / \mathrm{l} \mathrm{kinetin}$
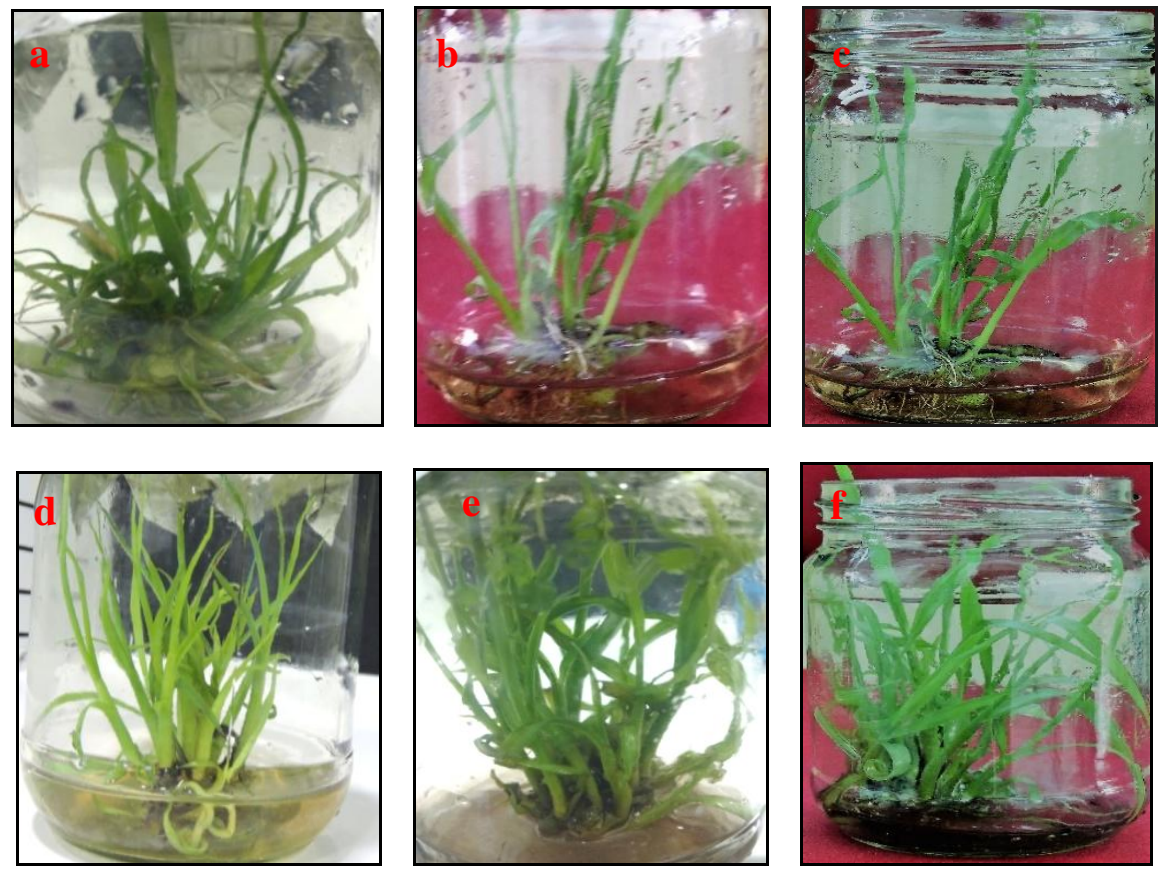
However, variety Co 86032 exhibited higher number of shoots per culture (17.37), shoot length (3.47), number of leaves (2.19) and high chlorophyll content $(15.40 \mathrm{mg} / \mathrm{g})$ compared to genotype CoVC-18061 (Table 3).

Shoot multiplication was observed at six different hormonal combinations without considering the genotype effects. The effect of different hormonal combination was found highly significant $(\mathrm{p}<0.001)$. Control (T1) showed lowest shoot multiplication rate per culture in both genotypes. Co 86032 exhibited highest number shoot per culture (22.75), shoot length (3.91), number of leaves (2.63) and high chlorophyll content (14.21) in liquid differentiating medium containing $1.0 \mathrm{mg} / \mathrm{l} \mathrm{6-}$ BAP and $0.5 \mathrm{mg} / \mathrm{l}$ kinetin (T3). MS medium fortified with combinations of $1.5 \mathrm{mg} / \mathrm{l} 6$ BAP and $0.5 \mathrm{mg} / \mathrm{l}$ kinetin, produced highest number of shoots per explant (18.25) with $5.03 \mathrm{~cm}$ shoot length, 2.13 leaves per shoot and chlorophyll content of $15.31 \mathrm{mg} / \mathrm{g}$ in CoVC-18061 (Table 4).

Among plant growth regulators, cytokinins have proven to be the most important factor affecting cell division, shoot regeneration, cell expansion, protein stimulation and activities of related enzymes in plants. Their significant effect may be related to the histological changes in induced tissues. The success of a culture is affected by type and concentration of applied cytokinins, because their uptake, transport and metabolism differ between genotypes and they can interact with endogenous cytokinins of an explant. The present study demonstrated the effect of cytokinins for shoot multiplication and elongation. Among various cytokinins, mainly two cytokinins viz., 6-BAP and kinetin were used in MS medium in various combinations. Variation in shoot multiplication among both the genotypes due different combination of cytokinins was reported. In case of $\mathrm{Co} 86032$, 6-BAP (1.0 $\mathrm{mg} / \mathrm{l})+$ kinetin $(0.5 \mathrm{mg} / \mathrm{l})$ proved to be best for higher shoot multiplication and elongation (Fig. 1). The results are in close agreement with Belay et al., (2014) who noticed maximum shoot formation on MS medium fortified with 6-BAP $(1.0 \mathrm{mg} / \mathrm{l})$ and kinetin $(0.5 \mathrm{mg} / \mathrm{l})$ in variety Co 86032 . The results revealed that MS medium fortified with 1.5 $\mathrm{mg} / \mathrm{l} 6-\mathrm{BAP}+0.5 \mathrm{mg} / \mathrm{l}$ kinetin was proved to be best for genotype CoVC-18061 for all characters evaluated (Fig. 2). Kambaska and Santilata (2009) in their investigation also reported that multiplication and elongation were higher when MS medium supplemented with $2.0 \mathrm{mg} / \mathrm{l}$ 6-BAP and $0.5 \mathrm{mg} / 1$ kinetin. Similar, findings were also reported by Melaku et al., (2016), and Dinesh et al., (2015). Similarly, Gopith et al., 2010 reported the use of kinetin with 6-BAP for shoot multiplication in sugarcane.

Differences in shoot multiplication in different combinations of 6-BAP and kinetin may due to the fact that different genotypes possess specific receptor proteins which exhibit varied response to different concentration of plant growth regulators. Sometimes differences in internal growth regulator contents of each genotype have suggested being reason for different in vitro responses of several plant species and variability between the genotypes within a species in micropropagation may be attributed to that differences.

In conclusion, in vitro shoot multiplication of one commercial sugarcane variety ' $\mathrm{Co}$ 86032' and an elite genotype 'CoVC-18061' has been developed. The result indicated that in vitro shoot multiplication of sugarcane is highly dependent on the interaction effects of 6-BAP, kinetin and genotype. Out of six combinations of 6-BAP and kinetin, MS medium fortified with $1.5 \mathrm{mg} / \mathrm{l6}$-BAP and 0.5 $\mathrm{mg} / \mathrm{l}$ kinetin was found superior for genotype, 
Co-86032 and exhibited best results for characters like shoots per explant, shoot length, leaves per shoot and chlorophyll content. MS medium with combination of 2 $\mathrm{mg} / \mathrm{l}$ 6-BAP and $0.5 \mathrm{mg} / \mathrm{l}$ kinetin was observed optimum for CoVC-18061 as it showed best results for all shoot characters. Thus, the developed protocol will help in minimizing the current challenges of sugarcane production by rejuvenating and availing adequate amount of quality disease free planting material of the sugarcane varieties within a short time.

\section{References}

Baksha R., Alam R., Karim M. Z., Paul S. K. and Hossain M. A. 2002. In vitro shoot tip culture of sugarcane (Saccharum officinarum L.) variety lsd 28. Biot., 1(3): 67-72.

Belay T., Mulugeta D. and Derbew B. 2014. Effects of 6-Benzyl aminopurine and Kinetin on In Vitro Shoot Multiplication of Sugarcane (Saccharum officinarum L.) Varieties. Adv. Crop. Sci. Tech., 2 (3): $1-5$.

Bhavan K. and Gautam. 2002. Micropropagation technology through tissue culture. Ind. council. for Agric. Res., 24-25.

Biradar S., Biradar B. P., Patil V. C. and Kambar N. S. 2009. In vitro plant regeneration using shoot tip culture in commercial cultivars of sugarcane. Karnat. J. Agri. Sci., 22: 21-24.

Dinesh P., Thirunavukkarasu P., Saraniya T. and Ramanathan. 2015. In Vitro Studies of Sugarcane Variety Co-91017 through Micropopagation of Shoot Tip Culture. Adv. Pl. Sci. and Agri. Res., 2(6):1-6.

Geetha S. And Padmanabhan D. 2001. Effect of hormones on direct somatic embryogenesis in sugarcane. Sugar Tech 3:120-121.

Gopitha K., Lakshmi B. A. and Senthil M.
2010. Effect of the different auxins and cytokinins in callus induction, shoot, root regeneration in sugarcane. Int. J. Pharma and Bio Sci., 1(3):1-7.

Kambaska K. B. and Santilata S. 2009.Rapid In vitro Micro propagation of Sugarcane (Saccharum officinarum L. cv-Nayana) Through Callus Culture. Nat. Sci., 7(4):1-10.

Khan S. A., Rashid A., Chaudhary M. F., Chaudhary Z. and Afroz A. 2008. Rapid Micropropagation of three elite Sugarcane (Saccharum officinarum L.) varieties by shoot tip culture. Afric. J. Biot., 7:2174-2180.

Khan S. A., Rashid H., Chaudry M. F., Chaudry Z. and Fatima S. U. 2009. Effect of cytokinins on shoot multiplication in three elite sugarcane varieties. Pak. J. Bot., 41: 1651-1658.

Krisnamurhi. and laskal J. 1994. Fiji disease resistant. Saccharum officinarum L. var. Pindar sub clone from tissue culture. Proc., 13: 130-137

Lakshmanan. 2012. Sugarcane tissue culture. Sugarcane for the future. Information sheet., 13034.

Lal M., Singh B. and Yadav G. C. 2001. Efficient protocols for micropropagation of sugarcane using shoot tip explant. Sugar Tech., 3: 113116.

Lal N. and Krishna R. 1994. Sugarcane and its problems: Tissue culture for pure and disease free seed production in sugarcane. Ind. Sugar. 44: 847-848.

Lee T. G. 1987. Micropropagation of sugarcane (Saccharum spp). Plant cell Tissue org. cult. 10: 47-55.

Lorenzo J. C., Ojeda E., Espinosa A. and Borroto C. 2001. Field performance of temporary immersion bioreactor derived sugarcane plants. Cell. Dev. Biol. Pl., 37: 803-806.

Mamun M. A., Sikdar M. B., Paul D. K., Mizanur M. and Rahman M. D. 2004. 
In vitro

Melaku T., Belayneh A. And Kassahun B. 2016. In Vitro Shoot Multiplication of Elite Sugarcane (Saccharum officinarum L.) Genotypes Using Liquid Shake Culture System. J. Biol. Agric. Healthc., 6(6):35-40.

Murashige T. and Skoog F. 1962. A revised medium for rapid growth and bio-assays with tobacco tissue cultures. Physiol. Pl., 15: 473-497.

Pathak S., Lal M., Tiwari A. K. and Sharma M. L. 2009. Effect of growth regulators on In vitro multiplication and rooting of shoot cultures in sugarcane. Sugar Tech., 11: 86-88.

\section{How to cite this article:}

Suresh Yadav, T.E. Nagaraja, H.C. Lohithaswa, K.V. Shivakumar, Poonam Kumari Yadav, Poonam Yadav, Ganpat Louhar and Jagdish Yadav. 2019. Genetic Response of Sugarcane (Saccharum officinarum L.) Genotypes to Varying Concentrations of Cytokinins for in vitro Shoot Multiplication. Int.J.Curr.Microbiol.App.Sci. 8(02): 1080-1088. doi: https://doi.org/10.20546/ijcmas.2019.802.127 